\title{
Electrophoretic profile of seminal proteins and their correlation with in vitro sperm characters in Black Bengal buck semen
}

\author{
M. Karunakaran, Vivek C. Gajare, Ajoy Mandal, Mohan Mondal, S. K. Das, M. K. Ghosh, S. Rai and R. Behera
}

\author{
ICAR-National Dairy Research Institute, Eastern Regional Station, Kalyani, West Bengal, India. \\ Corresponding author: M. Karunakaran, e-mail: drmkarunakaran@gmail.com \\ Co-authors: VCG: vivekgajare1@gmail.com, AM: ajoymandal@gmail.com, MM: drmmondal@gmail.com, \\ SKD: subratakdas1@gmail.com, MKG: monojghsh@rediffmail.com, SR: drsaroj.rai@gmail.com, \\ RB: drrajlaxmi.10@gmail.com \\ Received: 03-12-2018, Accepted: 08-03-2019, Published online: 03-05-2019
}

doi: 10.14202/vetworld.2019.621-628 How to cite this article: Karunakaran M, Gajare VC, Mandal A, Mondal M, Das SK, Ghosh MK, Rai S, Behera R (2019) Electrophoretic profile of seminal proteins and their correlation with in vitro sperm characters in Black Bengal buck semen, Veterinary World, 12(5): 621-628.

\begin{abstract}
Aim: This study aimed to study the electrophoretic properties of seminal plasma and sperm proteins of Black Bengal buck semen and their correlation with in vitro sperm characters and freezability.

Materials and Methods: Semen ejaculates from nine Black Bengal bucks were collected by artificial vagina ( $\mathrm{n}=20 / \mathrm{buck}$ ). Ejaculates were evaluated for in vitro sperm characters and electrophoretic profile of seminal protein. In vitro sperm characters were evaluated immediately after collection, after completion of equilibration period, and after freeze-thawing. For seminal protein studies, seminal plasma proteins were precipitated by ice-cold ethanol method, and sperm proteins were extracted by Triton X detergent extraction method. Discontinuous sodium dodecyl sulfate-polyacrylamide gel electrophoresis (SDS-PAGE) was performed to assess the molecular weight of seminal proteins. Correlation between in vitro sperm characters and protein bands was determined by Pearson's correlation coefficient, and two-way ANOVA was applied to find the individual buck differences.

Results: Significant difference $(\mathrm{p}<0.01)$ among the bucks was noticed in the in vitro sperm characters evaluated at all the three stages of semen evaluation such as immediately after collection, after completion of equilibration period, and post-freeze thawing. Progressive loss of sperm motility, membrane integrity, and other in vitro sperm characters were noticed during cryopreservation. A total of ten protein bands in the molecular weight ranging from 17 to $180 \mathrm{kDa}$ were found in the SDS-PAGE of seminal plasma proteins, while nine bands of 17-134 kDa were observed in sperm proteins. Seminal plasma proteins of molecular weight 75, 62-49, 20, and $17 \mathrm{kDa}$ and sperm proteins of 75, 20, and $17 \mathrm{kDa}$ were present in all the nine bucks $(100 \%)$ screened, and variation among the bucks was noticed for the presence of other proteins. Seminal plasma protein of $180-134 \mathrm{kDa}$ showed a negative correlation with individual motility $(-0.716)$ and functional membrane integrity of sperm cells $(-0.724)$ in post-freeze-thaw analysis and $48 \mathrm{kDa}$ protein had a positive correlation with individual motility (0.649) and functional membrane integrity of sperm cells $(0.664)$ in post-thaw analysis. Sperm proteins of $63 \mathrm{kDa}$ had a negative correlation $(-0.616)$ with sperm concentration in neat semen.
\end{abstract}

Conclusion: Variation among the bucks was noticed in the in vitro sperm characters and semen freezability. Correlation between seminal proteins and in vitro sperm characters and semen freezability had been found which might be useful as a tool to select breeding bucks.

Keywords: buck, in vitro characters, semen, seminal proteins.

\section{Introduction}

Animal husbandry and dairying are integral parts of human life since the process of civilization. Bengal goat is known for its meat and skin quality, adaptability, and high fecundity. It attains sexual maturity at an early age, and the female goat becomes pregnant twice a year and gives birth to 1-3 kids [1]. Black Bengal breed goats are found in West Bengal, Bihar, Jharkhand, Odisha, North Eastern India, and neighboring country Bangladesh. Most of the goat keepers are small and

Copyright: Karunakaran, et al. Open Access. This article is distributed under the terms of the Creative Commons Attribution 4.0 International License (http://creativecommons.org/licenses/ by/4.0/), which permits unrestricted use, distribution, and reproduction in any medium, provided you give appropriate credit to the original author(s) and the source, provide a link to the Creative Commons license, and indicate if changes were made. The Creative Commons Public Domain Dedication waiver (http:// creativecommons.org/publicdomain/zero/1.0/) applies to the data made available in this article, unless otherwise stated. marginal farmers, landless laborers having a flock size of 3-5 animals. Although the ratio of male and female kids at birth was 47.9:52.9, the ratio of sexually matured buck and doe was reduced to 1.13:88.7. This was mainly due to early castration and sale of the male goats at 9-12 months of age for meat purpose [2]. It leads to less availability of breeding bucks in the field, and the does are bred indiscriminately with available males and result in dilution/loss of valuable germplasm [3]. Artificial insemination (AI) technology has made possible the safe use of semen from selected sires in a large breeding female population. AI in goat is gaining popularity in several states of India such as Tamil Nadu, Kerala, West Bengal, Assam, and others for the past few years [4-6]. AI costs less when compared to keeping breeding buck(s) in small flocks of 3-5 goats, and the farmer has access to a wide variety of quality bucks of high genetic merit at relatively low cost. 
While adapting AI technology, accurate evaluation of male fertility is important because it influences the reproductive potential of a large population of females. Currently, breeding soundness examination (BSE) is carried out before introducing a male into the semen collection program. The variations in the fertility rate among the males which had passed through BSE were not addressed by the routine semen evaluation parameters [7]. Attention is now being directed toward the assessment of other aspects of semen quality as predictors of fertility. Proteins present in the seminal plasma and sperm have been reported as markers of fertility [8-10].

Seminal plasma, a complex mixture of secretions from the testis, epididymis, and accessory sex glands, contained factors that modulated the fertilizing ability of sperm [11]. The role of seminal plasma proteins in the regulation of sperm function was highly complex and was manifested during different molecular events. Several studies provided direct evidence that proteins of seminal plasma were adsorbed to the surface of sperm [12] and affected its function and properties [13]. Some of these proteins were probably adsorbed onto the surface so tightly that they would be inseparable or indistinguishable from the "intrinsic" membrane proteins, while others may be removed by simple washing [14]. The proteins were topographically reorganized into specific regions of the sperm surface and changed the properties of the sperm membrane by binding to it and/or modifying the structure or the arrangement of the existing membrane molecules. It was suggested that these proteins maintained the stability of membrane up to the process of capacitation. Capacitation and subsequent acrosome reaction reduced the content of proteins on the sperm surface, and approximately $35 \%$ of them only remained on the spermatozoa after acrosomal reaction [15]. Studies on the proteome of accessory sex gland fluid from sires of high and low fertility revealed the overexpression of seminal vesicle proteins, such as spermadhesins in low fertility sires and osteopontin in high fertility sires. Both proteins are produced in the seminal vesicles, and these proteins interact with the sperm membrane during capacitation and assist penetration of the oocyte [16]. Proteins such as osteopontin, prostaglandin-D synthase, bovine seminal plasma proteins (A1, A2, and A3), and heparin-binding proteins (HBPs) have been reported as indicators of bull fertility [16-18]. Although many works have been carried out on seminal proteins in bovine, equine, and other species, only a few studies have been carried out on buck semen.

Accumulating evidence has indicated that inherent male variability in semen freezability is one of the factors responsible for marked differences in the sperm cryosurvival $[19,20]$. Studies have reported that differences in sperm freezability might be due to a genetic origin [21]. Even though the underlying mechanisms responsible for the genetic differences associated with poor or good semen freezability are yet unknown, it has been suggested that the identification of sperm freezability markers might be the most efficient approach to improve the technology of semen cryopreservation. Considering the present demand and future scope of preserved goat semen, it is essential to identify markers for the selection of breeding bucks for semen donation.

This study aimed to study the in vitro sperm characters during different stages of cryopreservation, to isolate and characterize seminal plasma and sperm proteins, and to find the correlation between seminal proteins and in vitro sperm characters and semen freezability in Black Bengal buck semen.

\section{Materials and Methods}

\section{Ethical approval}

The experiment was carried out with the approval of the Institute Research Council of ICAR-National Dairy Research Institute (ICAR-NDRI), Karnal. Semen from the bucks was collected using artificial vagina as per the standard practice of semen collection from livestock species.

\section{Experimental animals}

The present study was carried out at ICARNDRI, Eastern Regional Station (ERS), Kalyani, West Bengal, India. Kalyani is situated at $22^{\circ} 58^{\prime} 30^{\prime}$ 'N latitude and $88^{\circ} 26^{\prime} 4^{\prime \prime}$ E longitude. The climatic condition is hot humid. Nine Black Bengal bucks (Capra hircus) were used in the study. Bucks were given with the identification tag numbers such as $46,48,51,52,53$, $55,57,59$, and 67 . All the experimental animals were clinically normal and donating semen of acceptable quality. Semen ejaculates were collected twice a week using artificial vagina. Before semen collection, bucks were sexually prepared by allowing 1-2 false mounts $[4,5]$. On every collection day, two ejaculates were collected from each buck with a brief interval. These two successive ejaculates from each buck were mixed; half was used for in vitro studies and another half was used for protein studies. A total of 20 ejaculates from each buck were used in the study. Semen ejaculates were collected during the period of November 2017-February 2018. Semen ejaculates with $3+$ and above mass motility and $70 \%$ and above individual motility were used in the study.

\section{Evaluation of in vitro sperm characters and freezing of semen}

Neat semen samples were evaluated for volume, sperm cell concentration (hemocytometer method), mass activity, abnormal count (Rose Bengal staining method), individual motility, and functional membrane integrity (hypo-osmotic swelling test [HOST]) immediately after collection [4,5]. After the initial evaluation, semen ejaculates were diluted 1:5 with Tris-fructosecitric acid-egg yolk-glycerol buffer and equilibrated at refrigeration temperature for $3 \mathrm{~h}$. Filling and sealing of straws were done manually in French Mini Straws during the equilibration period. After completion of 
equilibration, the semen straws were spread on plastic rack in a thermocol box $(35 \mathrm{~cm} \times 17 \mathrm{~cm} \times 20 \mathrm{~cm}) 10 \mathrm{~cm}$ above the liquid nitrogen level in static liquid nitrogen vapor. After pre-freezing for $10 \mathrm{~min}$ in the vapor, the straws were then plunged directly into liquid nitrogen and stored at $-196^{\circ} \mathrm{C}[4,5]$. Semen samples were evaluated for in vitro characters such as individual motility, functional membrane integrity, and concentration of malondialdehyde (MDA) (MDA; thiobarbituric acid-trichloracetic acid method) after completion of the equilibration and post-freezethawing of sperm cells.

\section{Extraction and characterization of seminal proteins}

The seminal plasma and sperm cells were separated immediately after collection by centrifugation $\left(560 \mathrm{~g}\right.$ for $10 \mathrm{~min}$ at $\left.5^{\circ} \mathrm{C}\right)$. The sperm cells were washed with $2 \mathrm{ml}$ of tris calcium chloride (TC) buffer (40 $\mathrm{mM}$ Tris, $2 \mathrm{mM} \mathrm{CaCl}_{2}$, and $0.01 \%$ sodium azide, $\mathrm{pH} 7.3$ ) by centrifugation $\left(560 \mathrm{~g}\right.$ for $5 \mathrm{~min}$ at $5^{\circ} \mathrm{C}$ ) to remove the leftover seminal plasma, if any. The sperm cells were resuspended with $1 \mathrm{ml}$ of TC buffer containing protease inhibitor (1 $\mathrm{mM}$ phenylmethylsulfonyl fluoride) and washed thrice by centrifugation (560 $\mathrm{g}$ for $10 \mathrm{~min}$ at $5^{\circ} \mathrm{C}$ ). The sperm pellet and the seminal plasma were stored at $-20^{\circ} \mathrm{C}$ until extraction of protein [12]. Proteins in the seminal plasma were precipitated by ice-cold ethanol method [22].
Sperm proteins were extracted by Triton $\mathrm{X}$ detergent extraction method [23]. Sodium dodecyl sulfate-polyacrylamide gel electrophoresis (SDS-PAGE) was performed to characterize the proteins based on molecular weight [24]. The gels were stained with Coomassie Brilliant Blue and destained in a mixture of methanol $(25 \%)$ and acetic acid (10\%) in distilled water. The apparent molecular mass was determined using molecular weight markers and gel documentation and analysis system and the gels were stored in acetic acid (7\%).

\section{Statistical analysis}

Correlation between in vitro sperm characters and protein bands obtained was determined by Pearson's correlation coefficient. Two-way ANOVA was applied to the effect of buck on in vitro sperm characters and different stages of semen preservation.

\section{Results}

\section{In vitro sperm characters}

Significant differences $(p<0.01)$ in the in vitro sperm characters were observed among the bucks in the neat semen (Table-1), after equilibration period and post-freeze thawing (Table-2). The mean \pm standard error of the mean (SEM) (range) of semen ejaculate volume $397.40 \pm 32.25 \mu 1$ (260.20 $\pm 6.66-490 \pm 16.33)$, sperm cell concentration

Table-1: In vitro sperm characters of neat semen samples in Black Bengal bucks.

\begin{tabular}{|c|c|c|c|c|c|c|}
\hline $\begin{array}{l}\text { Buck } \\
\text { number }\end{array}$ & Volume ( $\mu \mathrm{l})$ & $\begin{array}{l}\text { Concentration } \\
\text { (millions/ml) }\end{array}$ & $\begin{array}{c}\text { Mass } \\
\text { motility }\end{array}$ & $\begin{array}{c}\text { Individual } \\
\text { motility (\%) }\end{array}$ & $\begin{array}{c}\text { Functional membrane } \\
\text { integrity }(\%)\end{array}$ & $\begin{array}{l}\text { Abnormal } \\
\text { count }(\%)\end{array}$ \\
\hline 46 & $490 \pm 16.33^{a}$ & $2533.10 \pm 76.60^{b c}$ & $4.60 \pm 0.16^{a}$ & $72.40 \pm 1.06^{a}$ & $65.30 \pm 3.11^{b c}$ & $3.70 \pm 0.25^{\mathrm{b}}$ \\
\hline 48 & $485.20 \pm 36.55^{a}$ & $2594.10 \pm 31.48^{a b}$ & $3.40 \pm 0.26^{b}$ & $62.40 \pm 3.18^{\mathrm{bc}}$ & $58.00 \pm 2.32^{\text {de }}$ & $5.00 \pm 0.26^{a b}$ \\
\hline 51 & $485.20 \pm 56.29^{a}$ & $3020.10 \pm 80.86^{a}$ & $3.10 \pm 0.31^{b c}$ & $60.90 \pm 4.46^{\mathrm{bcd}}$ & $73.20 \pm 3.38^{a}$ & $4.70 \pm 0.30^{\mathrm{ab}}$ \\
\hline 52 & $415.20 \pm 22.42^{a}$ & $2339.60 \pm 20.00^{c}$ & $2.90 \pm 0.23^{b c}$ & $49.90 \pm 3.57^{e}$ & $61.40 \pm 2.79 \mathrm{bcd}$ & $4.90 \pm 0.31^{\mathrm{ab}}$ \\
\hline 53 & $425.20 \pm 13.43^{a}$ & $2417.40 \pm 36.5^{c}$ & $2.70 \pm 0.21^{\mathrm{c}}$ & $49.90 \pm 2.38^{\mathrm{e}}$ & $62.60 \pm 2.35^{\mathrm{bcd}}$ & $4.40 \pm 0.40^{\mathrm{ab}}$ \\
\hline 55 & $455.20 \pm 8.97^{a}$ & $2406.60 \pm 65.10^{c}$ & $3.80 \pm 0.20^{\mathrm{ab}}$ & $67.90 \pm 2.36^{\mathrm{ab}}$ & $71.70 \pm 2.61^{\mathrm{ab}}$ & $4.70 \pm 0.47^{a b}$ \\
\hline 57 & $290.20 \pm 12.47^{b}$ & $2486.60 \pm 73.41^{b c}$ & $2.80 \pm 0.20^{c}$ & $63.40 \pm 1.83^{a b}$ & $60.70 \pm 3.00^{\mathrm{cd}}$ & $4.80 \pm 0.33^{a b}$ \\
\hline 59 & $270.20 \pm 8.16^{b}$ & $2329.60 \pm 10.43^{c}$ & $2.70 \pm 0.15^{c}$ & $54.40 \pm 1.38^{\mathrm{de}}$ & $51.50 \pm 1.20^{\mathrm{e}}$ & $5.70 \pm 0.16^{a}$ \\
\hline 67 & $260.20 \pm 6.66^{b}$ & $2530.10 \pm 12.42^{b c}$ & $2.80 \pm 0.13^{c}$ & $55.40 \pm 1.17^{\text {cde }}$ & $51.80 \pm 0.92^{e}$ & $5.70 \pm 0.26^{a}$ \\
\hline Mean & $397.40 \pm 32.25$ & $2517.50 \pm 69.63$ & $3.20 \pm 0.21$ & $59.60 \pm 2.60$ & $61.80 \pm 2.53$ & $4.80 \pm 0.20$ \\
\hline
\end{tabular}

Data show all mean \pm SEM $(n=10)$. Means in a column with different superscripts $a, b, c$, , and e differ significantly at $p<0.01$. SEM $=$ Standard error of the mean

Table-2: In vitro sperm characters after completion of equilibration and post-freeze-thaw in Black Bengal bucks.

\begin{tabular}{|c|c|c|c|c|c|c|}
\hline \multirow[t]{2}{*}{ Buck number } & \multicolumn{3}{|c|}{ After completion of equilibration period } & \multicolumn{3}{|c|}{ Post-freeze-thaw } \\
\hline & $\begin{array}{c}\text { Individual } \\
\text { motility (\%) }\end{array}$ & $\begin{array}{c}\text { Functional } \\
\text { membrane } \\
\text { integrity }(\%)\end{array}$ & $\begin{array}{l}\text { Concentration of } \\
\text { MDA }(\mu \mathrm{mol} / \mathrm{ml})\end{array}$ & $\begin{array}{c}\text { Individual } \\
\text { motility (\%) }\end{array}$ & $\begin{array}{c}\text { Functional } \\
\text { membrane } \\
\text { integrity }(\%)\end{array}$ & $\begin{array}{l}\text { Concentration of } \\
\text { MDA }(\mu \mathrm{mol} / \mathrm{ml})\end{array}$ \\
\hline 46 & $56.50 \pm 1.42^{a}$ & $52.40 \pm 2.83^{a}$ & $0.28 \pm 0.08^{a}$ & $41.50 \pm 1.23^{a}$ & $42.30 \pm 1.60^{a}$ & $0.57 \pm 0.03^{a}$ \\
\hline 48 & $45.50 \pm 1.74^{b}$ & $43.20 \pm 1.76^{\mathrm{ab}}$ & $0.17 \pm 0.01^{b}$ & $30.00 \pm 1.67^{b}$ & $27.70 \pm 1.98^{b}$ & $0.32 \pm 0.03^{a}$ \\
\hline 51 & $44.00 \pm 2.77^{b}$ & $48.90 \pm 2.59^{a b}$ & $0.31 \pm 0.06^{\mathrm{ab}}$ & $26.50 \pm 1.83^{b}$ & $27.20 \pm 1.35^{\mathrm{b}}$ & $0.28 \pm 0.04^{a}$ \\
\hline 52 & $38.50 \pm 1.83^{b}$ & $39.10 . \pm 1.90^{\mathrm{ab}}$ & $0.18 \pm 0.04^{b}$ & $28.50 \pm 1.30^{\mathrm{b}}$ & $25.30 \pm 1.11^{b}$ & $0.38 \pm 0.03^{a}$ \\
\hline 53 & $38.50 \pm 1.98^{b}$ & $46.60 \pm 2.26^{b}$ & $0.20 \pm 0.06^{b}$ & $33.00 \pm 2.00^{\mathrm{ab}}$ & $30.80 \pm 1.57^{a b}$ & $0.45 \pm 0.04^{b}$ \\
\hline 55 & $49.50 \pm 2.63^{a}$ & $51.10 \pm 2.98^{a}$ & $0.30 \pm 0.03^{b}$ & $40.50 \pm 1.74^{a}$ & $36.40 \pm 2.10^{a}$ & $0.63 \pm 0.06^{a}$ \\
\hline 57 & $49.00 \pm 1.25^{a}$ & $44.30 \pm 1.45^{b}$ & $0.26 \pm 0.03^{c}$ & $34.50 \pm 1.17^{a b}$ & $27.10 \pm 0.65^{b}$ & $0.13 \pm 0.04^{b}$ \\
\hline 59 & $45.56 \pm 1.74^{b}$ & $41.90 \pm 1.31^{b}$ & $0.50 \pm 0.05^{c}$ & $39.00 \pm 2.08^{a b}$ & $34.30 \pm 1.76^{\mathrm{ab}}$ & $0.13 \pm 0.07^{b}$ \\
\hline 67 & $46.00 \pm 1.80^{\mathrm{b}}$ & $39.00 \pm 1.15^{\mathrm{b}}$ & $0.56 \pm 0.61^{c}$ & $35.50 \pm 1.89^{a b}$ & $29.20 \pm 4.36^{\mathrm{ab}}$ & $0.13 \pm 0.09^{b}$ \\
\hline Mean & $45.89 \pm 1.85$ & $45.00 \pm 1.64$ & $0.31 \pm 0.04$ & $34.30 \pm 3.78$ & $31.10 \pm 1.84$ & $0.33 \pm 0.06$ \\
\hline
\end{tabular}

Data show all mean \pm SEM $(n=10)$. Means in a column with different superscripts $a, b$, and $c$ differ significantly at $p<0.01$. $\mathrm{SEM}=$ Standard error of the mean, MDA=Malondialdehyde 
$2517.50 \pm 69.63 \mathrm{million} / \mathrm{ml}(2329.60 \pm 10.43-3020.10 \pm 80.86)$, mass motility $3.20 \pm 0.21(2.70 \pm 0.15-4.60 \pm 0.16)$, individual motility $59.60 \pm 2.60 \%(49.90 \pm 2.38-72.40 \pm 1.06)$, functional membrane integrity $61.80 \pm 2.53 \%$ (51.50 $\pm 1.20-73.20 \pm 3.38)$, and abnormal sperm count $4.80 \pm 0.20 \%$ (3.70 $\pm 0.25-5.70 \pm 0.26)$ was recorded in the neat semen samples of Black Bengal bucks.

The mean \pm SEM (range) of individual motility $\quad 45.89 \pm 1.85 \% \quad(38.50 \pm 1.83-56.50 \pm 1.42)$, functional membrane integrity $45.00 \pm 1.64 \%$ (39.00 $\pm 1.15-52.40 \pm 2.83)$, and concentration of MDA $0.31 \pm 0.04 \mu \mathrm{mol} / \mathrm{ml} \quad(0.20 \pm 0.06-0.56 \pm 0.61) \quad$ was observed after equilibration period. The values were further deteriorated and significantly reduced $(\mathrm{p}<0.01)$ after freeze-thawing of sperm cells. Individual motility was significantly $(\mathrm{p}<0.01)$ reduced to $34.30 \pm 3.78 \%$ against $45.89 \pm 1.85 \%$ at equilibration, and functional integrity was significantly $(\mathrm{p}<0.01)$ reduced to $31.10 \pm 1.84 \%$ against $45.00 \pm 1.64 \%$ at equilibration. Significant difference among the bucks in their ability to withstand freezing injuries was noticed.

\section{Electrophoretic profile of seminal plasma proteins}

A total of ten protein bands such as 180$136 \mathrm{kDa}, 134-101 \mathrm{kDa}, 75 \mathrm{kDa}, 62-49 \mathrm{kDa}, 48 \mathrm{kDa}$, 47-36 kDa, $35 \mathrm{kDa}, 34-25 \mathrm{kDa}, 20 \mathrm{kDa}$, and $17 \mathrm{kDa}$ were observed in the SDS-PAGE of seminal plasma proteins (Table-3). Of these 10 bands, 75, 62-49, 20, and $17 \mathrm{kDa}$ bands were present in all the nine bucks $(100 \%)$, while the other proteins such as $180-136$,
134-101, 48, 47-36, 35, and 34-25 $\mathrm{kDa}$ were present only $55.55 \%, 55.55 \%, 33.33 \%, 44.44 \%, 44.44 \%$, and $44.44 \%$, respectively, of the bucks screened.

\section{Electrophoretic profile of sperm proteins}

Electrophoretic profile of sperm proteins revealed the presence of nine bands starting from 17 to $134 \mathrm{kDa}$ (Table-4). Proteins with molecular weight 75, 20, and $17 \mathrm{kDa}$ were present in all the bucks screened (100\%), while the other proteins such as 134-101, 100, 62-49, $63,47-36$, and $35 \mathrm{kDa}$ were present only in $44.44 \%$, $55.55 \%, 66.66 \%, 44.44 \%, 55.55 \%$, and $33.33 \%$ of the bucks, respectively.

\section{Correlation between seminal plasma proteins and in vitro sperm characters}

Seminal plasma protein with molecular weight 180-136 kDa had shown a moderate positive correlation with sperm cell concentration (0.482) in neat semen (Table-5), while 134-101 kDa protein had shown a moderate positive correlation with functional membrane integrity $(0.576)$ and $48 \mathrm{kDa}$ shown a moderate positive correlation (0.454) with motility in post-equilibration period (Table-5). In the postfreeze-thaw evaluation, the $180-136 \mathrm{kDa}$ protein showed a significant negative correlation with individual motility $(-0.716)$ and functional membrane integrity $(-0.724)$. Further, the protein band of $48 \mathrm{kDa}$ showed a significant positive correlation with individual motility (0.649) and functional membrane integrity (0.664) and moderate positive correlation with MDA

Table-3: Electrophoretic profile of seminal plasma proteins of Black Bengal bucks assessed by SDS-PAGE.

\begin{tabular}{|c|c|c|c|c|c|c|c|c|c|c|}
\hline \multirow{2}{*}{$\begin{array}{l}\text { Protein } \\
\text { molecular } \\
\text { weight (kDa) }\end{array}$} & \multicolumn{9}{|c|}{ Buck numbers } & \multirow{2}{*}{$\begin{array}{l}\text { Overall presence of } \\
\text { protein }(n=9) \text { n }(\%)\end{array}$} \\
\hline & 46 & 48 & 51 & 52 & 53 & 55 & 57 & 59 & 67 & \\
\hline $180-136$ & - & + & + & + & - & - & + & - & + & $5(55.55)$ \\
\hline $134-101$ & + & - & + & - & + & + & - & + & - & $5(55.55)$ \\
\hline 75 & + & + & + & + & + & + & + & + & + & $9(100)$ \\
\hline $62-49$ & + & + & + & + & + & + & + & + & + & $9(100)$ \\
\hline 48 & + & - & - & - & - & + & - & + & - & $3(33.33)$ \\
\hline $47-36$ & - & + & - & - & + & - & + & + & - & $4(44.44)$ \\
\hline 35 & + & - & + & - & - & + & - & + & - & $4(44.44)$ \\
\hline $34-25$ & + & - & - & - & + & + & - & - & + & $4(44.44)$ \\
\hline 20 & + & + & + & + & + & + & + & + & + & $9(100)$ \\
\hline 17 & + & + & + & + & + & + & + & + & + & $9(100)$ \\
\hline
\end{tabular}

Figures in parentheses indicate percentage to total, - absence, + presence. SDS-PAGE=Sodium dodecyl sulfate-polyacrylamide gel electrophoresis

Table-4: Electrophoretic profile of sperm proteins of Black Bengal bucks assessed by SDS-PAGE.

\begin{tabular}{|c|c|c|c|c|c|c|c|c|c|c|}
\hline \multirow{2}{*}{$\begin{array}{l}\text { Protein molecular } \\
\text { weight (kDa) }\end{array}$} & \multicolumn{9}{|c|}{ Bucks numbers } & \multirow{2}{*}{$\begin{array}{l}\text { Overall presence of } \\
\text { protein }(n=9) n(\%)\end{array}$} \\
\hline & 46 & 48 & 51 & 52 & 53 & 55 & 57 & 59 & 67 & \\
\hline 134-101 & + & - & - & - & - & + & + & + & - & $4(44.44)$ \\
\hline 100 & + & + & + & + & + & - & + & - & + & $5(55.55)$ \\
\hline 75 & + & + & + & + & + & + & + & + & + & $9(100)$ \\
\hline $62-49$ & + & + & + & + & + & - & - & - & + & $6(66.66)$ \\
\hline 63 & - & - & - & + & + & + & + & + & - & $4(44.44)$ \\
\hline $47-36$ & + & - & + & - & - & + & + & + & - & $5(55.55)$ \\
\hline 35 & + & - & + & - & - & - & + & - & - & $3(33.33)$ \\
\hline 20 & + & + & + & + & + & + & + & + & + & $9(100)$ \\
\hline 17 & + & + & + & + & + & + & + & + & + & $9(100)$ \\
\hline
\end{tabular}

Figures in parentheses indicate percentage to total, - absence, + presence. SDS-PAGE=Sodium dodecyl sulfate-polyacrylamide gel electrophoresis 


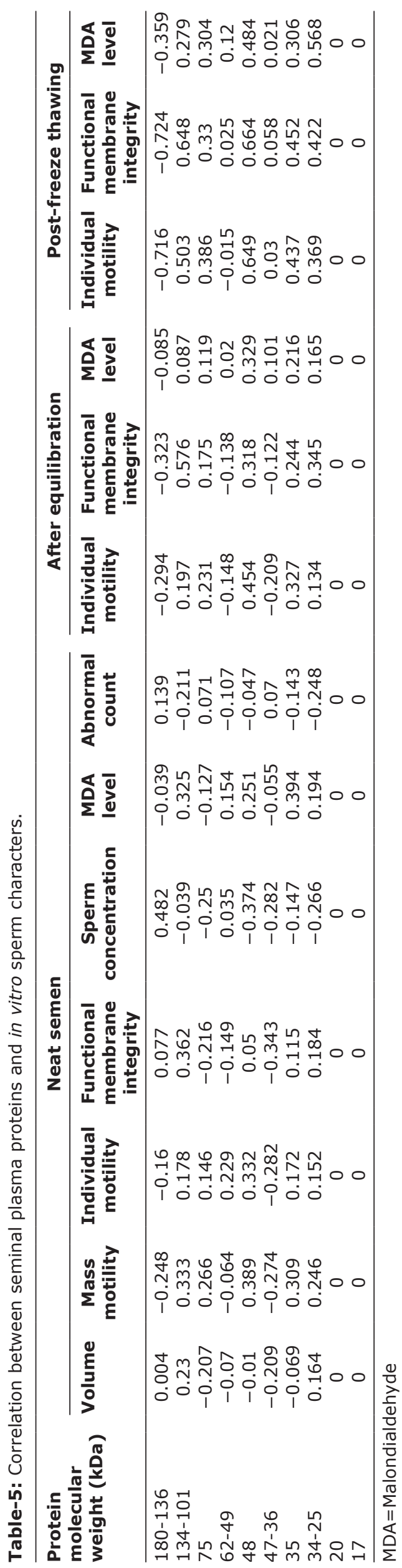

level (0.484). The protein band of $35 \mathrm{kDa}$ showed a moderate positive correlation with individual motility (0.437) and functional membrane integrity (0.452), while the 33-25 kDa protein showed a moderate positive correlation with functional membrane integrity (0.422) and MDA level (0.568).

\section{Correlation between sperm proteins and in vitro sperm characters}

The protein with molecular weight $134-101 \mathrm{kDa}$ had shown a moderate negative correlation with ejaculate volume $(-0.420)$, while $63 \mathrm{kDa}$ protein showed a significant negative correlation with sperm cell concentration $(-0.616)$ and moderate negative correlation with mass motility $(-0.465)$ in the neat semen samples (Table-6). The $63 \mathrm{kDa}$ protein showed a moderate negative correlation with individual motility $(-0.414)$ in post-equilibration samples, and the $100 \mathrm{kDa}$ protein had shown a moderate negative correlation with individual motility $(-0.564)$ in post-freeze-thaw samples.

\section{Discussion}

$\mathrm{AI}$ in goat is gaining popularity, and it is essential to identify bucks with high fertility for donating semen. A prerequisite for selecting a male as semen donor is that it should have acceptable fertility after AI. Accurate evaluation of male fertility is important because it influences the reproductive potential of large herd. In recent years, several proteins had been linked in some way or another to fertilizing capacity of sperm. While most of these proteins were associated with the seminal plasma, some were identified in sperm. The role of seminal plasma proteins in the regulation of sperm function was highly complex and was manifested during different molecular events. Several studies provided direct evidence that proteins of seminal plasma were adsorbed to the surface of sperm and affected its function and properties [25]. This experiment was an attempt to characterize seminal proteins of Black Bengal buck semen and to find their correlation with in vitro sperm characters and semen freezability. In the present study, an average of $397.40 \mu \mathrm{l}$ ejaculate volume, $2517.50 \mathrm{million} / \mathrm{ml}$ sperm cell concentration, 3.20 mass motility, $59.60 \%$ individual motility, $61.80 \%$ functional membrane integrity, and $4.80 \%$ abnormal sperm count was recorded in the neat semen of Black Bengal bucks. Semen ejaculates for the current experiment were collected during the period of November 2017-February 2018 which is winter season of the locality. However, in our previous observations, non-significant difference ( $p>0.05)$ was observed in the volume of ejaculate during different seasons; slightly larger volume of semen was obtained during the winter season $(0.70 \pm 0.2 \mathrm{ml})$ and lower volume during rainy season $(0.52 \pm 0.2 \mathrm{ml})$. Similarly, non-significant difference among the seasons was recorded for sperm motility also. Slightly

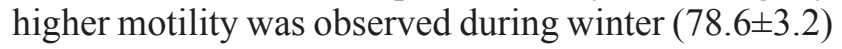

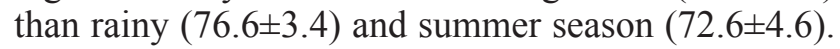
However, significantly $(\mathrm{p}<0.05)$ higher sperm cell 


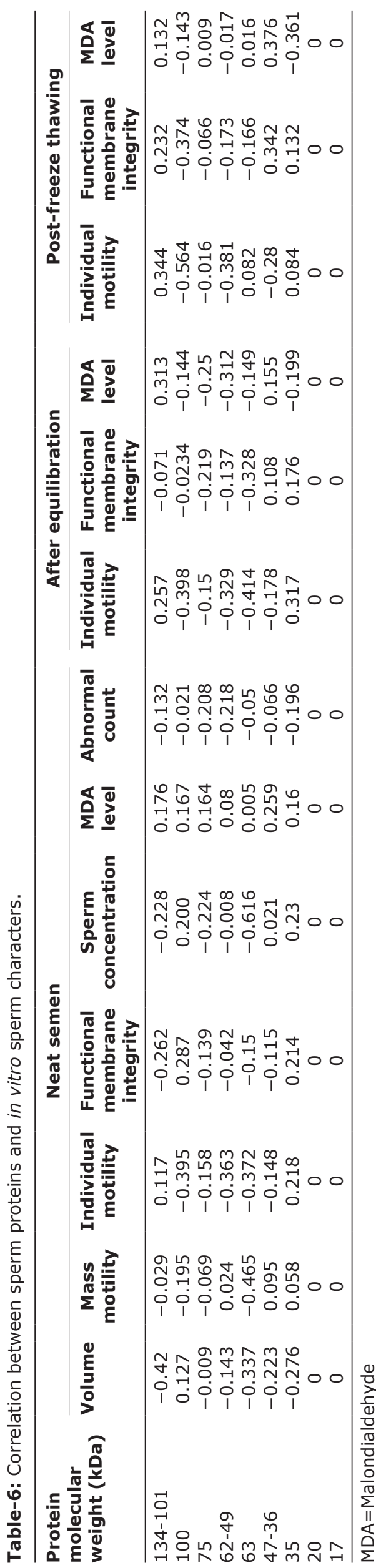

concentrations were recorded during rainy season $\left(3120 \times 10^{6} \pm 180 / \mathrm{ml}\right)$ than during summer season $\left(2440 \times 10^{6} \pm 140 / \mathrm{ml}\right)$ in the Black Bengal buck semen ejaculates. Similar to the present study, $0.39 \pm 0.01 \mathrm{ml}$ of ejaculate volume, $77.97 \pm 0.73 \%$ initial sperm motility, $3201.00 \pm 143.78 \times 10^{6} / \mathrm{ml}$ sperm concentration, $83.02 \pm 0.65 \%$ live sperm, $7.66 \pm 0.73 \%$ sperm abnormality, $66.95 \pm 0.74 \%$ HOST-reacted sperm, and $93.34 \pm 0.51 \%$ intact acrosome were reported in the neat semen of Assam Hill goat (AHG) [22]. In another study, $0.77 \mathrm{ml}$ ejaculate volume, $2.77 \times 10^{9} \mathrm{ml}^{-1}$ spermatozoa concentration, 3.19 mass activity, $68.57 \%$ individual motility, $15.5 \%$ dead cells, and $8.7 \%$ abnormal sperms were recorded in buck semen ejaculate [26].

The variations among the ejaculate characters in the different studies might be due to breed variations, frequency of semen collection, sexual preparation of bucks before collection, experience of the semen collector, management, and season of the year. It was observed that sperm motility and functional membrane integrity of the sperm cells were drastically reduced from their initial values after freeze-thawing of the semen. In concurrence to the observation, the loss of in vitro sperm characters was reported while freezing of Black Bengal buck semen in Triladyl and Tris-based diluents [27] and they had recorded 38.33\% and $6.00 \%$ sperm motility in rethawed semen samples in Triladyl and Tris diluents, respectively. Significant $(p<0.01)$ difference existed among the bucks in the sperm motility in fresh and frozen-thawed semen [27]. These findings indicate that there was progressive loss of in vitro sperm characters due to injury of cryopreservation. Cryopreservation induces detrimental effects in sperm cells, resulting in a loss of motility, membrane integrity, and fertilizing ability [28]. Under the best experimental conditions, about half the population of motile spermatozoa survive the freeze-thaw process. Buck sperm cells seem not well adapted to enduring cooling to low temperatures. There is a reduction of their post-thaw viability, as a consequence of accumulated cellular injuries that arise throughout the cryopreservation process [29].

Electrophoretic profile of seminal plasma Black Bengal buck semen revealed ten protein bands with molecular weight ranging from 17 to $180 \mathrm{kDa}$ in this study. 16 protein bands of $14-97 \mathrm{kDa}$ were reported in seminal plasma proteins of Anglo-Nubian goats [30], and 15 protein bands with molecular weight ranging from $15.13 \mathrm{kDa}$ to $116.20 \mathrm{kDa}$ were recorded in ram seminal plasma [31]. These variations might be due to the differences in the species, breed, methods of protein extraction and characterization. Electrophoretic profile of sperm proteins in this experiment revealed the presence of nine bands of 17-134 $\mathrm{kDa}$, while the seminal plasma proteins had 10 bands. The 180$136 \mathrm{kDa}$ protein band present in the seminal plasma of Bengal buck semen was not detected in the sperm proteins. SDS-PAGE of crossbred bulls' semen (Jersey 
crossbred and Holstein Friesian crossbred) recorded 15 and 14 proteins, respectively, in the seminal plasma and sperm [17]. Sperm membrane proteins in AHG revealed 20 different protein bands with molecular weight ranging from $10 \mathrm{kDa}$ to $75 \mathrm{kDa}$, and six bands such as $10,14,16,49,57$, and $60 \mathrm{kDa}$ were consistently present in all eight bucks [32].

Further, the protein with molecular weight 22, 30 , and $38 \mathrm{kDa}$ showed a frequency distribution of $87.50 \%$, and 28,45 , and $47 \mathrm{kDa}$ proteins had a frequency distribution of $75.00 \%$ in AHG. Seven protein bands with a molecular weight ranging from 29 to $200 \mathrm{kDa}$ were detected in porcine semen [33]. The comparative sequence analysis revealed strong similarities between certain seminal plasma proteins identified in several species. The amino acid sequence of the ram seminal plasma proteins RSVP14 showed high homology with goat seminal plasma proteins GSP-14/15 kDa [34].

Seminal plasma proteins had positive/negative correlation(s) with in vitro sperm characters during cryopreservation of Black Bengal buck semen. 180-136 kDa protein shown a moderate positive correlation with sperm cell concentration $(0.482)$ in neat semen, while 134 $101 \mathrm{kDa}$ protein shown a moderate positive correlation with functional membrane integrity $(0.576)$ and $48 \mathrm{kDa}$ protein shown a moderate positive correlation (0.454) with individual motility in post-equilibration period. In the post-freeze-thaw evaluation, $180-136 \mathrm{kDa}$ protein showed a significant negative correlation with individual motility $(-0.716)$ and functional membrane integrity $(-0.724)$. Similarly, the sperm protein of $63 \mathrm{kDa}$ showed a significant negative correlation with sperm cell concentration $(-0.616)$ and moderate correlation with mass motility $(-0.465)$ in the neat semen and moderate negative correlation with individual motility $(-0.414)$ in post-equilibration samples. In buffalo bull semen, $24.5 \mathrm{kDa}$ seminal plasma protein had a high correlation with sperm progressive motility in fresh and thawed semen, while $45 \mathrm{kDa}$ groups were associated with unusual morphology in frozen-thawed semen; $55 \mathrm{kDa}$ protein portions were connected with sperm viability of fresh semen [35]. Attempts have been made to analyze the roles of different protein fractions on the fertility of semen samples. Using two-dimensional gel electrophoresis, two seminal plasma proteins correlated with high fertility (26 and $55 \mathrm{kDa}$ ) and two proteins with low fertility (16 and $16 \mathrm{kDa}$ ) had been identified in bulls [36]. The $55-\mathrm{kDa}$ fertility-associated protein has been identified as osteopontin [37], and the 26-kDa protein as lipocalin-type prostaglandin-D synthase [38]. HBP with a molecular weight of 28-31 kDa in the sperm membrane was named as fertility-associated antigen (FAA). Bull semen with the presence of FAA in sperm membranes had increased fertility by $9-40 \%$ points under natural service [38] and about $15 \%$ higher conception rate on AI. Spermatozoal FAA was shown to be a significant marker for fertility, even if bulls displayed similar behavioral serving capacities [39]. As like that of other species, identification of fertility-associated proteins in the buck semen will be of much useful for selection of breeding bucks for AI purpose.

\section{Conclusion}

Variations among the bucks exist in their in vitro sperm characters, seminal plasma protein profiles, and ability to withstand freezing injury. Seminal proteins influence the in vitro sperm characters and could be used as a supplementary tool in addition to BSE for the selection of breeding bucks.

\section{Authors' Contributions}

MK designed the study. VCG collected the samples and performed the experiments. AM, MM, and SKD helped in running SDS-PAGE; MKG, SR, and RB helped in semen analysis, MK and AM analyzed the data. MK and VCG wrote the manuscript, and all authors read and approved the final manuscript.

\section{Acknowledgments}

The authors are thankful to Director, ICARNDRI, Karnal, and Head, ICAR-NDRI-ERS, Kalyani, for providing facilities to carry out the experiment. Authors are also thankful to The Department of Biotechnology, Government of India for providing facilities through the project (grant No. BT/PR21104/ SPD/24/773/2017). We would like to thank the veterinarians and workers at ICAR-NDRI-ERS, Kalyani, for their valuable help during the experiment.

\section{Competing Interests}

The authors declare that they have no competing interests.

\section{Publisher's Note}

Veterinary World remains neutral with regard to jurisdictional claims in published institutional affiliation.

\section{References}

1. Chowdhury, S.A., Bhuiyan, M.S.A. and Faruk, S. (2002) Rearing black Bengal goat under semi-intensive management. Asian Australas. J. Anim. Sci., 15(1): 477-484.

2. Nandi, D., Roy, S., Bera, S., Kesh, S.S. and Samanta, A.K. (2011) The rearing system of black Bengal goat and their farmers in West Bengal, India. Vet. World, 4(6): 254-257.

3. Khandoker, M.A.M., Apu, A.S., Husain, S.S. and Notter, D.R. (2011) A baseline survey on the availability of black Bengal breeding bucks in different districts of Bangladesh. J. Bangladesh Agric. Univ., 9(1): 91-96.

4. Konyak, P., Mandal, A., Mondal, M., Bhakat, C., Das, S.K., Saroj, R., Ghosh, M.K. and Karunakaran, M. (2018) Preservation of black Bengal buck semen in soybean lecithin based chemically defined extender. Indian J. Anim. Res., 52(8): 1151-1154.

5. Karunakaran, M., Konyak, P., Mandal, A., Mondal, M., Bhakat, C., Mandal, D.K., Das, S.K. and Ghosh, M.K. (2017) Chemically well-defined extender for preservation of black Bengal buck semen. Res. Rev. J. Dairy Sci. Technol., 6(2): 7-10.

6. Karunakaran, M., Konyak, P., Mandal, A., Mondal, M., Bhakat, C., Saroj, R., Ghosh, M.K. and Behera, R. (2019) Effect of trehalose-an impermeant cryoprotectant on 
cryopreservation of black Bengal buck semen. Indian $J$. Anim. Res., 53(1): 37-40.

7. Larson, J.L. and Miller, D.J. (2000) Can relative spermatozoal galactosyltransferase activity be predictive of dairy bull fertility? J. Dairy Sci., 83(11): 2473-2479.

8. Karunakaran, M., Devanathan, T.G., Jawahar, T.P., Manimaran, K., Chitra, A., Dhali, A. and Selvaraju, S. (2012) Electrophoretic profile of bull sperm membrane proteins as a tool for selection of breeding bulls. Indian $J$. Anim. Sci., 82(11): 1303-1305.

9. Karunakaran, M., Devanathan, T.G., Kulasekar, K., Sridevi, P., Jawahar, T.P., Loganathasamy, K., Dhali, A. and Selvaraju, S. (2012) Effect of heparin-binding protein and hydrogen peroxide on lipid peroxidation status of bovine sperm cells. Indian J. Anim. Sci., 82(9): 976-978.

10. Karunakaran, M., Devanathan, T.G., Kulasekar, K., Sridevi, P., Jawahar, T.P., Loganatahsamy, K., Dhali, A. and Selvaraju, S. (2012) Effect of fertility associated protein on oxidative stress of bovine sperm cells. Indian J. Anim. Reprod., 33(1): 43-46.

11. Krishnan, G., Thangvel, A., Loganathasamy, K., Veerapandian, C., Kumarasamy, P. and Karunakaran, M. (2015) Effect of fertility associated proteins on lipid peroxidation production in Holstein Friesian semen. Indian $J$, Anim. Sci., 85(11): 1176-1180.

12. Desnoyers, L. and Manjunath, P. (1992) Major proteins of bovine seminal plasma exhibit novel interactions with phospholipid. J. Biol. Chem., 267(14): 10149-10155.

13. Yanagimachi, R. (1994) Fertility of mammalian spermatozoa: Its development and relativity. Zygote, 2(4): 371-372.

14. Russell, L.D., Montag, B., Hunt, W. and Peterson, R.N. (1985) Properties of boar sperm plasma-membranes (pm)-proteins released by washing and differential solubility in salts, detergents, and sensitivity to surface radiolabeling. Gamete Res., 11: 237-252.

15. Caballero, I., Vazquez, J.M., Garcia, E.M., Roca, J., Martınez, E.A., Calvete, J.J., Sanz, L., Ekwall, H. and Rodriguez-Martınez, H. (2006) Immunolocalization and possible functional role of pspipsp-ii heterodimer in highly extended boar spermatozoa. J. Androl., 27(6): 766-773.

16. Moura, A.A., Koc, H., Chapman, D.A. and Killian, G.J. (2006) Identification of proteins in the accessory sex gland fluid associated with fertility indexes of dairy bulls: A proteomic approach. J. Androl., 27(2): 201-211.

17. Karunakaran, M. and Devanathan T.G. (2016) Evaluation of bull semen for fertility-associated protein, in vitro characters and fertility. J. Appl. Anim. Res., 45(1): 136-144.

18. Krishnan, G., Thangvel, A., Loganathasamy, K., Veerapandian, C., Kumarasamy, P. and Karunakaran, M. (2016) The presence of heparin-binding proteins and their impact on semen quality of Holstein Friesian bulls. Indian J. Anim. Sci., 86(4): 392-396.

19. Prien, S. and Iacovides, S. (2016) Cryoprotectants and cryopreservation of equine semen: A review of industry cryoprotectants and the effects of cryopreservation on equine semen membranes. J. Dairy Vet. Anim. Res., 3(1): 1-8.

20. Gürler, H., Malama, E., Heppelmann, M., Calisici, O., Leiding, C., Kastelic, J.P. and Bollwein, H. (2016) Effects of cryopreservation on sperm viability, synthesis of reactive oxygen species and DNA damage of bovine sperm. Theriogenology, 86(2): 562-571.

21. Thurston, L.M., Siggins, K., Mileham, A.J., Watson, P.F. and Holt, W.V. (2002) Identification of amplified restriction fragment length polymorphism markers linked to genes controlling boar sperm viability following cryopreservation. Biol. Reprod., 66(3): 545-554.

22. Asadpour, R., Alavi-Shoushtari, S.M., Rezaii, S.A. and Ansari, M.K. (2007) SDS-polyacrylamide gel electrophoresis of buffalo bulls seminal plasma proteins and their relation with semen freezability. Anim. Reprod. Sci., 102(3-4): 308-313.

23. Nass, S.J., Miller, D.J., Winner, M.A. and Ax, R.L. (1990) Male accessory sex glands produce heparin-binding proteins that bind to cauda epididymal spermatozoa and are testosterone dependent. Mol. Reprod. Dev., 25(3): 237-246.

24. Laemmli, V.K. (1970) Cleavage of structural proteins during the assembly of the head of bacteriophage T4. Nature, 227(5259): 660-685.

25. Purdy, P. (2006) A review on goat sperm cryopreservation. Small Rumin. Res., 63(3): 215-225.

26. Afroz, S., Islam, M., Khandoker, M. and Akter, Q. (2008) Cryopreservation of black Bengal buck semen: Effects of diluents and freezing on sperm motility and morphology. Anim. Sci. J., 79(5): 550-553.

27. Apu,A.S., Khandoker, M.A.M., Husain, S.S., Rahman, S.M.H. and Notter, R.D. (2008) Investigation of seminal attributes and fertility of black Bengal goat. Bangladesh J. Anim. Sci., 37(2): 17-24.

28. Watson, P.F. (1995) Recent developments and concepts in the cryopreservation of spermatozoa and the assessment of their post-thawing function. Reprod. Fertil. Dev., 7(4): 871-891.

29. Teixeira, D., Cavada, B., Sampaio, A., Havt, A., Bloch, C Jr., Prates, M., Moreno, F., Santos, E., Gadelha, C., Gadelha, T., Crisostomo, F. and Freitas, V. (2002) Isolation and partial characterisation of a protein from buck seminal plasma (Capra hircus), homologous to spermadhesins. Protein Pept. Lett., 9(4): 331-335.

30. Yue, W., Shi, L., Bai, Z., Ren, Y. and Zhoa, Y. (2009) Sodium dodecyl sulfate (SDS)-polyacrylamide gel electrophoresis of ram seminal plasma proteins and their correlation with semen characteristics. Anim. Reprod. Sci., 116(3-4): 386-391.

31. Deori, S., Deka, B., Biswas, R., Nahardeka, N., Arangasamy, A., Bhuyan, D., Kalita, D., Borah, R. and Phookan, A. (2018) Characteristics and freezability of Assam Hill goat semen. Indian J. Anim. Res., 52(1): 25-28.

32. Karunakaran, M., Ratnakaran, U., Naik, P.K. and Chakurkar, E.B. (2016) Electrophoretic profile of boar seminal proteins. J. Appl. Anim. Res., 44(1): 403-405.

33. Barrios, B., Fernández, J.M., Muiño, B.T. and Cebrián, P.J.A. (2005) Immuno-cytochemical localization and biochemical characterization of two seminal plasma proteins that protect ram spermatozoa against cold shock. J. Androl., 26(4): 539-549.

34. Villemure, M., Lazure, C. and Manjunath, P. (2003) Isolation and characterization of gelatin-binding proteins from goat seminal plasma. Reprod. Biol. Endocrinol., 1: 39-45.

35. Killian, G.J., Chapman, D.A. and Rogowski, L.A. (1993) Fertility associated proteins in Holstein bull seminal plasma. Biol. Reprod., 49(6): 1202-1207.

36. Cancel, A.M., Chapman, D.A. and Killian, G.J. (1997) Osteopontin is the 55-kilodalton fertility-associated protein in Holstein bull seminal plasma. Biol. Reprod., 57(6): 1293-1301.

37. Gerena, R.L., Irikura, D., Urade, Y., Eguchi, N., Chapman, D.A. and Killian, G.J. (1998) Identification of a fertility-associated protein in bull seminal plasma as lipocalin-type prostaglandin D synthase. Biol. Reprod., 58(3): 826-833.

38. Bellin, M.E., Oyarzo, J.N., Hawkins, H.E., Zhang, H., Smith, R.G., Forrest, D.W., Sprott, L.R. and Ax, R.L. (1998) Fertility-associated antigen on bull sperm indicates fertility potential. J. Anim. Sci., 76(8): 2032-2039.

39. Sprott, L.R., Harris, M.D., Forrest, D.W., Young, J.H., Zhang, M., Oyarzo, J.N., Bellin, M.E. and Ax, R.L. (2000) Artificial insemination outcomes in beef females using bovine sperm with a detectable fertility-associated antigen. J. Anim. Sci., 78(4): 795-798. 